\title{
Isolation and Properties of an Inducible and a Constitutive $\beta$-Lactamase from Pseudomonas aeruginosa
}

\author{
By MARY BERKS (NÉE MCPHAIL), KEITH REDHEAD AND \\ EDWARD P. ABRAHAM* \\ Sir William Dunn School of Pathology, University of Oxford, South Parks Road, \\ Oxford OXI 3RE, U.K.
}

(Received 13 May 1981; revised 7 July 1981)

\begin{abstract}
The inducible $\beta$-lactamase from Pseudomonas aeruginosa NCTC 8203 and the constitutive $\beta$-lactamase from strain $1822 \mathrm{~S} / \mathrm{H}$ have been isolated and compared. These two enzymes are apparently periplasmic since they are released by freezing and thawing. They resemble each other closely in their molecular weights, amino acid composition, isoelectric points and electrophoretic mobility as well as in their catalytic properties, and they may be identical. Neither enzyme contains a free thiol group.
\end{abstract}

\section{INTRODUCTION}

The production of an inducible cell-bound $\beta$-lactamase by Pseudomonas aeruginosa was first observed with strain NCTC 8203 (Sabath \& Abraham, 1964; Sabath et al., 1965). This type of inducible $\beta$-lactamase appeared to be species specific and mediated by a chromosomal gene (Sykes \& Richmond, 1971). A constitutive $\beta$-lactamase was later shown to be produced by a carbenicillin-resistant mutant (strain $1822 \mathrm{~S} / \mathrm{H}$ ) of $P$. aeruginosa $18 \mathrm{~S}$ and was not distinguished from the inducible-type enzyme it its substrate profile and electrophoretic mobility at $\mathrm{pH} 8.5$ (Flett et al., 1976).

A purified preparation of the inducible $\beta$-lactamase from strain 8203 was described by McPhail \& Furth (1973). The isolation of both the inducible and constitutive $\beta$-lactamase and a comparison of their properties are reported in the present paper.

\section{METHODS}

Chemical methods. Protein was determined routinely by the method of Goa (1953) and occasionally from the quotient $A_{260} / A_{280}$ (Layne, 1957). Isoelectric focusing was carried out in polyacrylamide gel in a Multiphor isoelectric focusing apparatus (LKB-Produkter, Bromma, Sweden). Molecular weights were estimated (a) by filtration through a column of Sephadex G-100 in $1 \%(\mathrm{w} / \mathrm{v}) \mathrm{NH}_{4} \mathrm{HCO}_{3}$ (Andrews, 1964) and (b) by sodium dodecyl sulphate-polyacrylamide gel electrophoresis (SDS-PAGE) (Weber \& Osborn, 1969). Amino acid analysis was as described by Baldwin et al. (1979), cystine being determined after oxidation as cysteic acid. Thiol groups were determined by the method of Ellman (1959) before and after reduction of disulphide with $\mathrm{NaBH}_{4}$ (Moore et al., 1959; Cavallini et al., 1966). The ability of the constitutive $\beta$-lactamase to crystallize was examined by the vapour diffusion method of McPherson (1976).

Assay of $\beta$-lactamase activity. The unit of $\beta$-lactamase activity used is the amount of enzyme which hydrolyses $1 \mu \mathrm{mol}$ substrate $\min ^{-1}$ at $30^{\circ} \mathrm{C}$ and $\mathrm{pH} 8 \cdot 0$. Assays were carried out with a recording $\mathrm{pH}$-Stat (Radiometer, Copenhagen) with cephalosporin $\mathrm{C}(5 \mathrm{~mm})$ as substrate.

Production and isolation of $\beta$-lactamases. Pseudomonas aeruginosa NCTC 8203 was grown in shake flasks and $\beta$-lactamase production induced with 6-aminopenicillanic acid as reported by McPhail \& Furth (1973); $P$. aeruginosa $1822 \mathrm{~S} / \mathrm{H}$ (kindly provided by Professor M. H. Richmond) was grown similarly except that no inducer was added. Larger scale cultures were grown under similar conditions in a 15 I fermenter (type LHE $1 / 1000$ from L. H. Engineering Co., Stoke Poges, Bucks, U.K.). The $\beta$-lactamases were released from the bacteria by freezing and thawing (McPhail \& Furth, 1973). 
Purification of the $\beta$-lactamases by chromatography on Sephadex CM-50 followed by chromatography on DEAE-Sephadex was as reported by McPhail \& Furth (1973), but the products eluted from DEAE-Sephadex still contained a substantial amount of inactive protein. Selected fractions of the eluate were chromatographed on a

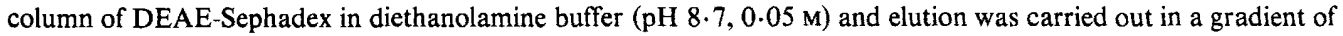
$\mathrm{NaCl}$ in the same buffer. Both $\beta$-lactamases were eluted as a single band, over most of which the enzymic activity closely paralleled the protein activity. The two pooled eluates were dialysed against $5 \mathrm{~mm}-\mathrm{NH}_{4} \mathrm{HCO}_{3}$ and freeze-dried without loss of activity.

Tryptic digestion. Samples of $\beta$-lactamase $(2 \mathrm{mg})$ in water were kept at $60^{\circ} \mathrm{C}$ for $5 \mathrm{~min}$. The resulting suspension of unfolded protein was centrifuged $(4000 \mathrm{~g}, 45 \mathrm{~min})$ and the precipitate resuspended in $1 \mathrm{ml}$ of $1 \%$ $(\mathrm{w} / \mathrm{v}) \mathrm{NH}_{4} \mathrm{HCO}_{3}, \mathrm{pH} 7.95$. A sample $(5 \mu \mathrm{l})$ of a $1 \%$ solution of trypsin in $1.2 \mathrm{mM}-\mathrm{HCl}$ was added to the suspension and the mixture shaken at $37^{\circ} \mathrm{C}$. The mixture became clear within about $15 \mathrm{~min}$. After $1 \mathrm{~h}$ a further $5 \mu \mathrm{l}$ of trypsin solution was added and the incubation continued for a further $1 \mathrm{~h}$. The digest was then freeze-dried.

\section{RESULTS AND DISCUSSION}

No gross morphological changes were observed in the two strains of $P$. aeruginosa on liberation of the $\beta$-lactamases by freezing and thawing. This would be consistent with the view that both $\beta$-lactamases are periplasmic.

Nearly $40 \mathrm{mg}$ of the inducible $\beta$-lactamase and up to $70 \mathrm{mg}$ of the constitutive $\beta$-lactamase were obtained from 71 of culture. The elution curve for the inducible enzyme from the final column of DEAE-Sephadex is shown in Fig. 1(b). The corresponding curve for the constitutive enzyme was similar. The increase in purification over that at the previous stage (Fig. $1 a$ ) was about $20 \%$.

The specific activities of both $\beta$-lactamases were close to 1000 units (mg protein) ${ }^{-1}$, corresponding to catalytic centre activities (molecules cephalosporin $\mathrm{C}$ transformed per $\mathrm{s}$ per catalytic centre) of about 700 on the assumption that the molecular weight of each enzyme is 42000 (see below). These activities were at least twice that of the preparation of the inducible enzyme obtained by McPhail \& Furth (1973), whose purification procedure did not include the final chromatographic stage described here. The constitutive enzyme yielded orthorhombic crystals $(2 \mathrm{~mm} \times 0.1 \mathrm{~mm})$ from aqueous polyethylene glycol.

Both $\beta$-lactamase preparations showed a single protein band with $\beta$-lactamase activity after electrophoresis of samples $(20 \mu \mathrm{g})$ in polyacrylamide gel at $\mathrm{pH} 9.5$ (Fig. $2 a$ ). Both enzymes migrated $1.4 \mathrm{~cm}$ towards the cathode under the conditions used and were not distinguishable on the same gel. However, when the amount of $\beta$-lactamase applied to the gel was increased 10 -fold, both enzymes showed three minor bands with $\beta$-lactamase activity, in addition to the main band, that were indistinguishable on the same gel (Fig. $2 b$ ). The minor bands appeared to account for about $10 \%$ of the total protein. Both $\beta$-lactamase preparations also showed one major band of $\beta$-lactamase (isoelectric at $\mathrm{pH} 8 \cdot 1$ ) on isoelectric focusing, but in this case up to ten very minor bands with detectable $\beta$-lactamase activity were observed, corresponding to proteins with isoelectric points varying from $\mathrm{pH} 8$ to $\mathrm{pH}$. Most of these minor bands reappeared when isoelectric focusing was repeated with the protein eluted from the major band and were thus probably due to proteins that were absent from the original preparations.

The molecular weights found here for both $\beta$-lactamases were 42000 by SDS-PAGE and 32000 by gel filtration, in contrast to the findings of McPhail \& Furth (1973) who obtained a value of 42000 for the inducible enzyme by both methods. Considerable differences in the molecular weights given by these two procedures have also been obtained with other $\beta$-lactamases (Ross, 1975; Richmond \& Sykes, 1973; Dale \& Smith, 1976). A value of 42000 has been used here in subsequent calculations.

The amino acid compositions of the two $\beta$-lactamases did not differ significantly and were similar to those reported by McPhail \& Furth (1973) with one exception. McPhail \& Furth (1973) stated that the inducible enzyme contained one mol cysteine per mol protein, and a thiol group that became accessible to Ellman's reagent after denaturation of the protein. No free thiol group could be detected in the preparations described here before reduction of 

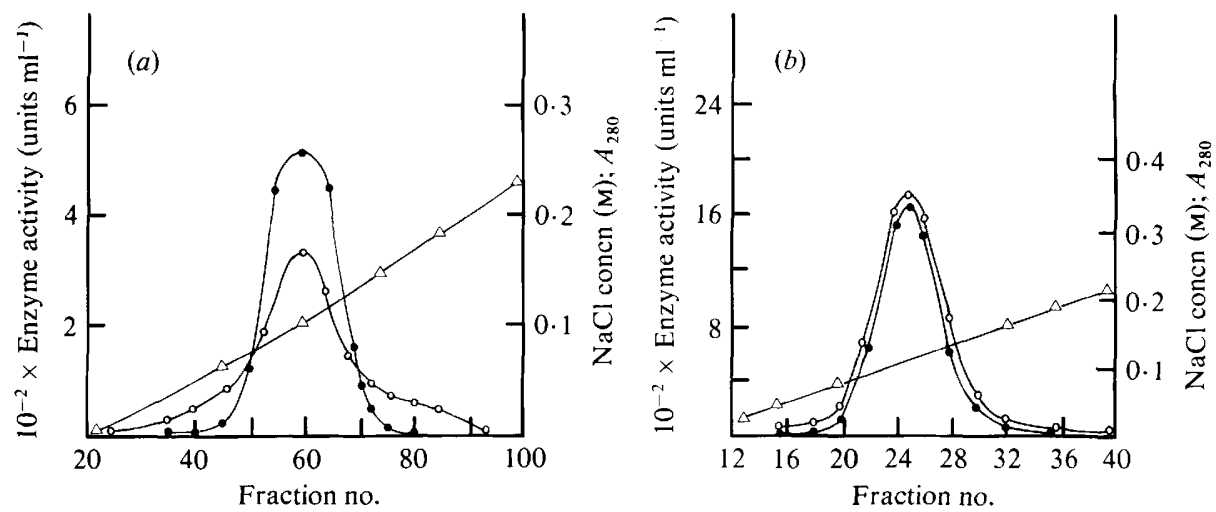

Fig. 1. Chromatography of the inducible $\beta$-lactamase from strain 8203 . (a) A solution of $\beta$-lactamase (290 mg, 180 units $\mathrm{mg}^{-1}$ ) eluted from Sephadex CM-50 was dialysed against diethanolamine buffer ( $\mathrm{pH}$ $8.7,0.05 \mathrm{M})$ and added to a column $(15 \times 6 \mathrm{~cm}$ diam. $)$ of DEAE-Sephadex equilibrated with the same buffer. The $\beta$-lactamase was eluted with a gradient of $\mathrm{NaCl}$ in buffer. The flow rate was $30 \mathrm{ml} \mathrm{h}^{-1}$ and fractions were collected every $10 \mathrm{~min}$. Fractions 50 to 68 were pooled. (b) The $\beta$-lactamase from column $(a)$ was chromatographed similarly on a column $(6 \times 2.4 \mathrm{~cm}$ diam. $)$ of DEAE-Sephadex. The flow rate was $33 \mathrm{ml} \mathrm{h}^{-1}$ and fractions were collected every $10 \mathrm{~min}$. Fractions 21 to 30 were pooled. , $\beta$-Lactamase activity; $\mathrm{O}, A_{280} ; \triangle$, concentration of $\mathrm{NaCl}$.

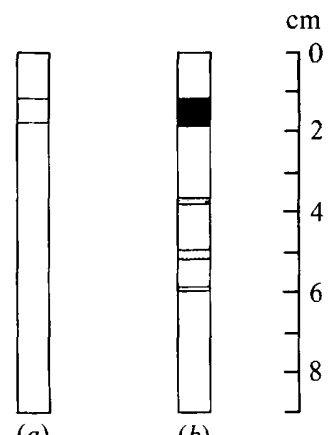

(a)

(b)

Fig. 2. Disc gel electrophoresis of $\beta$-lactamases. Electrophoresis was carried out in $5 \%(\mathrm{w} / \mathrm{v})$ polyacrylamide at $\mathrm{pH} 9.5$ for $45 \mathrm{~min}$ and at constant current ( $5 \mathrm{~mA}$ per disc gel) as described by Smith (1968). Protein was detected by staining with $0.25 \%(\mathrm{w} / \mathrm{v})$ Coomassie brilliant blue in methanol/acetic $\mathrm{acid} /$ water ( $5: 1: 5$, by vol.). $\beta$-Lactamase activity was detected by application to the gel of Whatman no. 1 paper moistened with nitrocefin (O'Callaghan et al., 1972). The inducible and constitutive $\beta$-lactamases were each applied to gels in amounts of $(a) 20 \mu \mathrm{g}$ and $(b) 200 \mu \mathrm{g}$. The two $\beta$-lactamases showed indistinguishable patterns when tested separately or as a mixture. The diagram indicates the positions and intensities of bands stained for protein. The protein in all these bands showed $\beta$-lactamase activity.

disulphide groups with $\mathrm{NaBH}_{4}$. After reduction, about $1.0 \mathrm{~mol} \mathrm{SH}$ per mol protein was present in preparations at the penultimate stage of purification (Fig. $1 \mathrm{a}$ ) but only $0.3 \mathrm{~mol}$ per mol protein at the final stage (Fig. $1 \mathrm{~b}$ ). Amino acid analysis after oxidation and hydrolysis of the final products revealed the presence of $0.2-0.3 \mathrm{~mol}$ cysteic acid per mol protein. It is concluded that neither $\beta$-lactamase contains a free thiol group and that the cystine content of the preparations $(0 \cdot 1-0 \cdot 15 \mathrm{~mol}$ per mol protein) can be attributed to minor components which may have $\beta$-lactamase activity.

No clear evidence for differences in the primary structures of the two enzymes was obtained from peptide maps of tryptic digests, which yielded 32 or 33 distinct spots (Fig. $3 a$, $b$ ). No additional spots were observed in maps of mixtures of the two digests. 


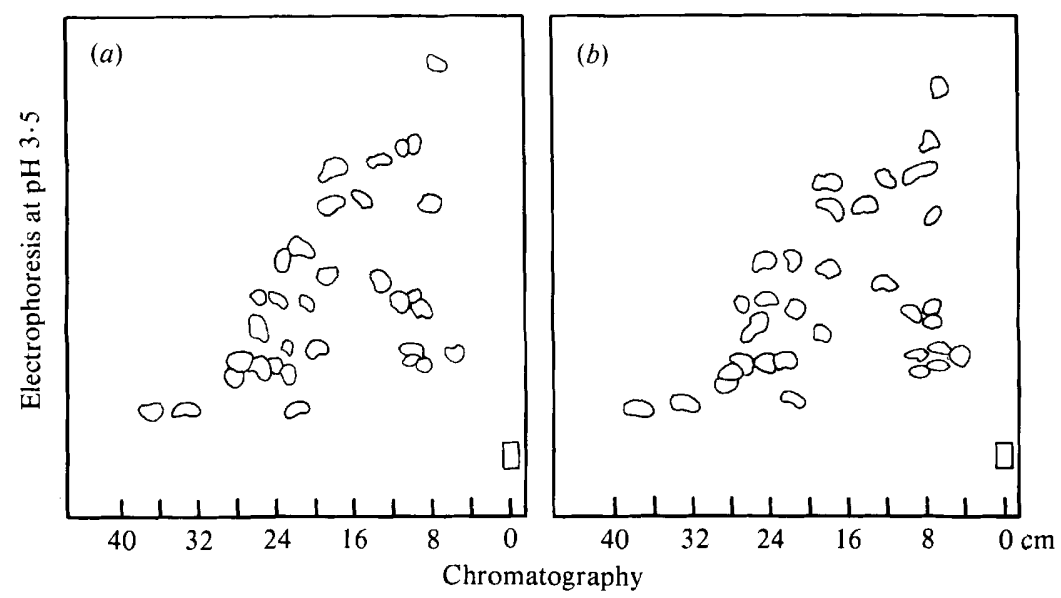

Fig. 3. Tracings of peptide maps of $\beta$-lactamase digests. (a) Constitutive enzyme from strain $1822 \mathrm{~S} / \mathrm{H}$ and $(b)$ inducible enzyme from strain 8203 . Samples of tryptic digests of about $2 \mathrm{mg} \beta$-lactamase were applied to Whatman no. 1 paper in the area boxed round in the Figures (bottom right). After chromatography in butan-1-ol/acetic acid/water/pyridine (30:6:24:20, by vol.), a strip of paper $(2.5 \mathrm{~cm}$ wide) containing the peptides was cut out and sewn on to fresh paper. Electrophoresis was then carried out in the second direction in pyridine acetate buffer, $\mathrm{pH} 3.5$, at $70 \mathrm{~V} \mathrm{~cm}^{-1}$ for $45 \mathrm{~min}$. Peptides were detected with the cadmium-ninhydrin reagent.

\section{Table 1. Behaviour of substrates or inhibitors with $\beta$-lactamases from P. aeruginosa}

Rates of hydrolysis (relative to those of benzylpenicillin) were determined in a pH-Stat at $\mathrm{pH} 8.0$ and $30^{\circ} \mathrm{C}$. Substrate concentrations were 4 or $5 \mathrm{~mm}$ and in most cases the rates are close to $V_{\max }$. Values of $K_{\mathrm{i}}$, which correspond to Michaelis constants for competitive inhibitors that are also substrates (Kiener \& Waley, 1978), were estimated by the method of Hunter \& Downs (1945) with benzylpenicillin $\left(K_{\mathrm{m}} 15 \mu \mathrm{M}\right)$ or cephalosporin $\mathrm{C}\left(K_{\mathrm{m}} 500 \mu \mathrm{M}\right)$ as substrate.

\begin{tabular}{|c|c|c|c|c|}
\hline \multirow[b]{2}{*}{$\beta$-Lactam compound } & \multicolumn{2}{|c|}{$\begin{array}{l}\beta \text {-Lactamase from } \\
\text { strain } 8203\end{array}$} & \multicolumn{2}{|c|}{$\begin{array}{l}\beta \text {-Lactamase from } \\
\text { strain } 1822 \mathrm{~S} / \mathrm{H}\end{array}$} \\
\hline & $V(\%)$ & $K_{\mathrm{i}}(\mu \mathrm{M})$ & $V(\%)$ & $K_{1}(\mu \mathrm{M})$ \\
\hline Benzylpenicillin & 100 & & 100 & \\
\hline Carbenicillin & 1.9 & 0.3 & & 0.3 \\
\hline Cloxacillin & $<1.0$ & 0.013 & $<1.0$ & 0.014 \\
\hline Methicillin & $<1.0$ & $0 \cdot 18$ & $<1.0$ & 0.20 \\
\hline Phenoxymethylpenicillin & 75 & & 75 & \\
\hline Cephalosporin C & 610 & & 590 & \\
\hline Cephalothin & 410 & & 400 & \\
\hline Cephaloridine & 300 & & 290 & \\
\hline Cephalexin & 50 & & 54 & \\
\hline Cephamandole & $4 \cdot 0$ & 1.34 & $4 \cdot 0$ & \\
\hline Cefuroxime & 1.0 & $0 \cdot 3$ & $1 \cdot 0$ & \\
\hline Cefoxitin & 0.5 & $0 \cdot 17$ & 0.5 & \\
\hline
\end{tabular}

The $\mathrm{pH}$-activity profiles of the two $\beta$-lactamases between $\mathrm{pH} 6$ and $\mathrm{pH} 10$, with cephalosporin $\mathrm{C}$ as substrate and at $30^{\circ} \mathrm{C}$, were closely similar in shape and showed maximum activity at $\mathrm{pH} 8 \cdot 5$. Relative rates of hydrolysis of a number of penicillins and cephalosporins are given in Table 1 . The rates for the inducible and constitutive $\beta$-lactamase did not differ significantly from each other when both enzymes were tested against the same substrate. Cloxacillin, methicillin and carbenicillin showed high affinities for both enzymes and were powerful competitive inhibitors. Both 5-epi- and 6-epibenzylpenicillin, which were tested only against the inducible $\beta$-lactamase, were poor substrates and showed very low affinities for this enzyme, their apparent $K_{\mathrm{f}}$ values being $0.25 \mathrm{~mm}$ and $5.0 \mathrm{~mm}$ respectively. 
The affinities of the penicilloates from benzylpenicillin and methicillin for the inducible enzyme were too low to be measured under the conditions used.

Both $\beta$-lactamases were rapidly and completely inactivated during their hydrolysis of cephalosporin $87 / 312$ (nitrocefin), but the rate of hydrolysis was too high for an attempt to isolate a covalently linked complex of this substrate with the inactivated enzyme to be feasible. However, cloxacillin has a high affinity for these $\beta$-lactamases and a low value for $V_{\max }$. Knott-Hunziker et al. (1980) have labelled the constitutive $\beta$-lactamase described here with $\left[{ }^{3} \mathrm{H}\right]$ cloxacillin and have obtained an acyl enzyme in which an active-site serine residue is acylated.

The constitutive and inducible $\beta$-lactamases are closely similar in both their chemical and catalytic properties. The production of the constitutive $\beta$-lactamase in high yield is consistent with the suggestion (Flett et al., 1976) that $\beta$-lactamase synthesis in the mutant $1822 \mathrm{~S} / \mathrm{H}$ is fully derepressed.

We are indebted to the Medical Research Council and the National Research Development Corporation for financial support. We thank Mr T. Beesley for assistance and Dr S. G. Waley for helpful discussions.

\section{REFERENCES}

ANDREwS, P. (1964). Estimation of the molecular weights of proteins by Sephadex gel-filtration. Biochemical Journal 91, 222-233.

Baldwin, G. S., Waley, S. G. \& Abraham, E. P. (1979). Identification of histidine residues that act as zinc ligands in $\beta$-lactamase II by differential tritium exchange. Biochemical Journal 179, 459-463.

Cavallini, D., Graziani, M. T. \& Dupré, S. (1966). Determination of disulphide groups in proteins. Nature, London 212, 294-295.

Dale, J. W. \& SMITH, J. T. (1976). The dimeric nature of an R-factor mediated $\beta$-lactamase. Biochemical and Biophysical Research Communications 68 , 1000-1005.

Ellman, G. L. (1959). Tissue sulfhydryl groups. Archives of Biochemistry and Biophysics 82, 70-77.

Flett, F., Curtis, N. A. C. \& Richmond, M. H. (1976). Mutant of Pseudomonas aeruginosa 18S that synthesizes type Id $\beta$-lactamase constitutively. Journal of Bacteriology 127, 1585-1586.

GoA, J. (1953). A micro biuret method for protein determination. Determination of total protein in cerebrospinal fluid. Scandinavian Journal of Clinical and Laboratory Investigation 5, 218-222.

Hunter, A. \& Downs, C. E. (1945). The inhibition of arginase by amino acids. Journal of Biological Chemistry 157, 427-446.

Kiener, P. S. \& Waley, S. G. (1978). Reversible inhibitors of penicillinase. Biochemical Journal 169 , 197-204.

Knott-Hunziker, V., Redhead, K., Petursson, S. \& WALEY, S. G. (1980). $\beta$-Lactamase action: isolation of an active serine peptide from the Pseudomonas enzyme and a penicillin. FEBS Letters 121, 8-10.

LAYNE, E. (1957). Spectrophotometric and turbidimetric methods for measuring proteins. Methods in Enzymology 3, 447-454.

MCPhaIl, M. \& Furth, A. J. (1973). Purification and properties of an inducible $\beta$-lactamase from Pseudomonas aeruginosa N.C.T.C. 8203. Biochemical Society Transactions 1, 1260-1263.

MCPherson, A. (1976). Crystallization of proteins from polyethylene glycol. Journal of Biological Chemistry 251, 6300-6303.

Moore, S., Cole, R. D., Gundleach, H. G. \& Stein, W. H. (1959). On the cleavage of disulfide bonds in proteins by reduction. Proceedings, Fourth International Congress of Biochemistry, vol. VIII, pp. 52-62.

O'C allaghan, C. H., Morris, A., Kirby, S. M. \& SHINGLER, A. H. (1972). Novel method for the detection of $\beta$-lactamases by using a chromogenic cephalosporin substrate. Antimicrobial Agents and Chemotherapy 1, 283-288.

Richmond, M. H. \& Sykes, R. B. (1973). The $\beta$-lactamases of Gram-negative bacteria and their possible physiological role. Advances in Microbial Physiology 9, 31-88.

Ross, G. W. (1975), $\beta$-Lactamase (Enterobacter species). Methods in Enzymology 43, 678-687.

Sabath, L. D. \& Abraham, E. P. (1964). Synergistic action of penicillins and cephalosporins. Nature. London 204, 1066-1069.

Sabath, L. D., Jago, M. \& A Braham, E. P. (1965). Cephalosporinase and penicillinase activities of a $\beta$-lactamase from Pseudomonas pyocyanea. Biochemical Journal 96, 739-752.

SmitH, I. (1968). Zone electrophoresis. In Chromato graphic and Electrophoretic Techniques, vol. II, pp. 365-389. Edited by I. Smith. London: Heinemann.

Sykes, R. B. \& Richmond, M. H. (1971). R factors, beta-lactamase, and carbenicillin-resistant Pseudomonas aeruginosa. Lancet ii, 342-344.

Weber, K. \& OsBorn, M. (1969). The reliability of molecular weight determinations by dodecyl sulfatepolyacrylamide gel electrophoresis. Journal of Biological Chemistry 244, 4406-4412. 